\title{
Teaching Writing Recount Text Using Receipts as Media of the Eighth Grade Students
}

\author{
Wahyuni \\ SMPN 5 Sidoarjo, email: yuniagung123@ymail.com
}

\section{Sulistyaningsih}

STKIP PGRI Sidoarjo, email: sulistyaningsih3112@gmail.com

\begin{abstract}
This study was purposed to describe the implementaion of teaching writing recount text by using receipts and to describestudents' cognitive responds in writing recount text by using receipts as media. This study was quantitative research and used experimental method. The quasi experimental was used as the research design and test was the instrument. The students of the eighth grade of SMP Negeri 5 Sidoarjo were as the sample. The number of students in this study was 66 people that 33 people were experimental class students and 33 people were as controlled class students. The SPSS 20 was used to calculate the data. It was proven that sig. 2 tailed ( $p$ ) was for the test of hypothesis proved that sig. 2 tailed ( $p$ ) was 0.049 while alpha ( $\alpha$ ) was 0.05. In other words, $p<\alpha$. It meant that the Ho (Null Hypothesis) was denied and Ha (Alternative Hypothesis) was allowed. It was proven that it had a positive effect of using receipts to students' writing skill of recount text. Moreover, the result of Cohen's formulation calculation proved the effect size of receipts result was 0.49 . It can be concluded that the effect of this treatment was modest effect.
\end{abstract}

Keywords: writing, recount text, receipts

\section{INTRODUCTION}

Writing is one of four skills in English language learning that students at SMP Negeri 5 Sidoarjo must achieve. In reality, their writing skill was very apprehensive because it was under the minimum score criteria (KKM). It was caused by the teacher who did not have enough competence to harness the media of learning. The teacher always used the lecture method. Teachers are more active and students are passive but the teacher also asks questions to keep the students attentive. As a result, they were bored and noisy to join the learning process. The worst impact, they did not have the techniques of writing as like the way to gain ideas about what they will write on, to determine the right diction, to arrange sentence, to carry out them chronologically and coherently, to invigorate and then to rectify the composition until they could produce good writing or get score either as high as KKM. To improve the low students' writing skill, the researcher as teacher must change the learning method to teach the writing skill of recount text more interestingly. 
According to M. Atar Semi (2007: 14) the purpose of writing, among others: a) to tell something, b) to provide instructions or direction, c) to explain something, d) to convince, and e) to summarize. As cited in Lestari's, writing skills are one's skills in pouring thoughts, ideas, by using a series of good written languages and right. A person's writing skills will be good if he also has: (a) the ability to find the problem to be written, (b) sensitivity to the condition of the reader, (c) the ability to draw up a research plan, (d) the ability to use Indonesian, (e) the ability to start writing, and (f) the ability to check your own essay. Those abilities will develop if supported by reading activities and a wealth of vocabulary it has. Similarly, Budinuryanta and friends, (1997: 12.1) Writing skills are not obtained "naturally", but must be studied and practiced in earnest.

According to Anderson \&Anderson (1997: 48) a recount is speaking or writing about past events or a piece of text that retells past events, usually in the order which they happened. There for the experience of the readers themselves, such as their adventure and their day's activities. Soeprapto and Darwis (2006:7) define recount as a piece of text that retells past events, usually in the order in which they happened. The purpose of a recount text is to give the audience a description of what and when it happened. Beside recount text as the study material must be achieved by students of SMP in Indonesia, that is stated in the Curriculum 2013 at the Basic Competence 4.11.2, specifically recount text is a text that tells about something that happened in the past. Something that happened in the past can be called experience. As cited by Rohmah, Maria states that recount text has two types like as personal recount, historical events or biographies recount. Personal recount is about story of a person that the writer or the speaker has been in the event participated and historical or biographies recount aims to retell the chronology of activities. According to F. A Soeprapto and Mariana Darwis on their book stated that recount text aims to give information or entertainment to audiences or readers. It retells about past experience of people that happened. In other word, it can inform or entertain the readers while they are reading the written story. Three points have to be presented in recount text and called the schematic structure of recount text. Generic structures of texts define the aim of the texts. As stated by Risma the generic structure of recount text has three points. Those are such as a. Orientation put in the first of the text that informs the background to influence the audience get the text and performs the settings and people who take a part; it exposes the location of the event, the time when the event occurred; b. Series of event inform the events was occurred that ordered in chronological series; c. Reorientation is in the last paragraph of recount text. It is about the summary of the whole events. 
Receipt was used in this research, because it was always received by the students when they went to the public facilities that provided and gave it to the consumers as a proof of purchase in a transaction, generally in shopping activities. According to Market Business News at https://marketbusinessnews.com/financial-glossary/receipt/ that receipt is a piece of paper or electronic document confirming that the seller received money from the purchaser and includes the date and a description of the item the purchaser bought. As cited from Business at https://www.business.gov.au/finance/payments-and-invoicing/receipts-and-proof-of-purchase states that a receipt or proof of purchase may be printed from a cash register, hand written or a tax invoice. Any receipt or proof of purchase you give your customers must include: (a) your business name and Australian business number (ABN) or Australian company number (ACN, (b) the date of supply, (c) the details on the product or service, (d) the price.

As media receipt has benefit. According to Aqib (2015: 51) those are: 1) delivering uniformed material; 2) Learning is clearer and more interesting; 3) The learning process is more interaction; 4) Efficiency of time and energy; 5) Improve the quality of learning outcomes; 6) Learning can be done anytime and anywhere; 7) Growing a positive attitude towards learning about learning processes and materials.; 8) Increase the teacher's role in a more positive and productive direction. The purpose of applying receipt in tis study was to make students retell a recount story easily and without concepting it will be able to lead students to write recount text. Based on the above statements, the objectives of this study is to describe the implementation of teaching writing recount text through receipt as media of the eighth grade students and to describe the student's cognitive response in writing recount text by using receipts.

\section{METHOD}

The quantitative research was used in this research because it had statistical calculation to calculate the data. Furthermore, experimental design was used as a method to try a new technique in teaching writing recount text through using receipt in the chosen classes. Two classes were used for this study, one as a control group and the other one as an experiment group. The control group was not taught recount text using receipt, the other one was the experimental class was taught recount text using receipt as the treatment.

The study used quasi-experimental design that did not randomly assign the participants as in true experimental. Djarwanto (1994: 420) stated population is the total number of units or individuals whose characteristics are to be studied. And these units are called units of analysis, and can be people, institutions, things. Sugiyono (2010: 61) http://fatkhan.web.id/pengertian-populasi-sampel-jenis-sampling-dan-teknik-sampling/ states 
that the population is a generalization area that consists of objects / subjects that have certain quantities and characteristics determined by researchers to be studied and then drawn conclusions. The population was not only people, but also other natural objects. Population was also not just the number of objects / subjects studied but includes all the characteristics / properties possessed by the object or subject.

The population of the study was the eighth grade students of SMP Negeri 5 Sidoarjo in academic year 2018/2019. The total class of the eighth grade were eight classes VIII-1, VIII-2, VIII-3, VIII-4, VIII-5, VIII-6, VIII-7, and VIII-8. The eight classes consist of 33 students in each class.-According to Arikunto (2006: 131) stated sample is part or as a representative of the population to be studied. If the research is carried out part of the population, it can be said that the research is a sample research. People, institutions, objects. Sugiyono (2010: 60) stated sample is a portion of the number and characteristics possessed. The sample used in this study was the class of VIII-4 as the experiment class and the controlled class was class of VIII-3. The total sample for the study was 66 students. The pre- and post-test of the classess were as the instruments.

This study had three variables, the receipt acted as the independent variable, while students' writing skill and recount text acted as the dependent variable. This study was aimed to decribe how the implementation of using receipt on writing recount text of the students and to describe the students' cognitive responds. The method of data collection is a technique or method used to collect data. The method designated a method so that its use can be demonstrated through questionnaires, interviews, observations, tests, documentation and so on. The data collection was taken from the results of the test consists of pre-test and post-test. In the pre-test, students were given an essay test before implementing service to know and decide which one would be the experimental and which one would be the controlled class. In the posttest, students had the same items as the pre-test. The post-test given after implementing service to find progress of students writing recount text after receiving the service.

The data analysis used automatically calculation and analysis which was from the software Microsoft Excel 2007 and SPSS 20 that had the significance level of 0.05. To obtain the contrast of the means scores of experimental and control class student. There were normality, homogeneity, and hypothesis test in it. It purposed to find the contrast of means of scores of both experimental and control group, the t-test in which the two groups of larger samples correlated each other was used. 


\section{RESULTS}

Below was the data collection of pre and post-test score of writing recount text of experimental and controlled class students. Their descriptions were in the experimental class and controlled class table. They were explained through the presented data as followed:

Table. 1. Pre-test and Post-test Score of experimental class students

\begin{tabular}{|c|c|c|c|c|}
\hline No & Student's name & Pre-test & Post-test & Gained score \\
\hline 1 & A & 62 & 50 & -12 \\
\hline 2 & $\mathrm{~B}$ & 42 & 56 & 14 \\
\hline 3 & $\bar{C}$ & 26 & 45 & 19 \\
\hline 4 & $\mathrm{D}$ & 75 & 85 & 10 \\
\hline 5 & $\mathrm{E}$ & 77 & 83 & 6 \\
\hline 6 & $\mathrm{~F}$ & 68 & 88 & 20 \\
\hline 7 & $\mathrm{G}$ & 16 & 76 & 60 \\
\hline 8 & $\mathrm{H}$ & 51 & 79 & 28 \\
\hline 9 & $\mathrm{I}$ & 67 & 86 & 19 \\
\hline 10 & $\mathrm{~J}$ & 17 & 42 & 25 \\
\hline 11 & $\mathrm{~K}$ & 36 & 76 & 40 \\
\hline 12 & $\mathrm{~L}$ & 42 & 54 & 12 \\
\hline 13 & $\mathrm{M}$ & 67 & 74 & 7 \\
\hline 14 & $\mathrm{~N}$ & 42 & 63 & 21 \\
\hline 15 & $\mathrm{O}$ & 79 & 91 & 12 \\
\hline 16 & $\mathrm{P}$ & 69 & 94 & 25 \\
\hline 17 & $\mathrm{Q}$ & 70 & 96 & 26 \\
\hline 18 & $\mathrm{R}$ & 80 & 91 & 11 \\
\hline 19 & $\mathrm{~S}$ & 20 & 33 & 13 \\
\hline 20 & $\mathrm{~T}$ & 40 & 61 & 21 \\
\hline 21 & $\mathrm{U}$ & 37 & 76 & 39 \\
\hline 22 & $\mathrm{~V}$ & 72 & 93 & 21 \\
\hline 23 & $\mathrm{~W}$ & 55 & 83 & 28 \\
\hline 24 & $\mathrm{X}$ & 22 & 57 & 35 \\
\hline 25 & $\mathrm{Y}$ & 27 & 46 & 19 \\
\hline 26 & $\mathrm{Z}$ & 42 & 55 & 13 \\
\hline 27 & $\mathrm{~A} 1$ & 54 & 65 & 11 \\
\hline 28 & B1 & 54 & 64 & 10 \\
\hline 29 & $\mathrm{C} 1$ & 34 & 67 & 33 \\
\hline 30 & D1 & 29 & 42 & 13 \\
\hline 31 & E1 & 57 & 69 & 12 \\
\hline 32 & F1 & 17 & 66 & 54 \\
\hline \multirow[t]{5}{*}{33} & G1 & 76 & 94 & 18 \\
\hline & SUM & 1536 & 2300 & 683 \\
\hline & MEAN & 46.54545454 & 69.69696969 & 20.69696969 \\
\hline & MAXIMUM SCORE & 80 & 96 & \\
\hline & MINIMUM SCORE & 16 & 33 & \\
\hline
\end{tabular}


From the result of data analysis, it could be concluded that in the experimental class there was a modest distinction between students' writing skill of recount text after treating the receipts and the controlled class which was not treated with receipts in learning writing recount text. The experimental class students obtained the pretest mean score 46.55, but their post-test mean score was 69.70. Therefore, their gained mean score was 20.70. The lowest score in the pre-test was 15 and the highest score was 80 . Meanwhile, the highest post-test score is 96 and the lowest is 33. The table shows an increase in the students' scores post applying receipt in teaching writing of recount text. Particularly, this also can be concluded that the score of preand post - test student's achievement was different significantly in the table. Furthermore, the pre-test and post-test of controlled class students was shown in the table 2 below.

Table No. 2. The Pre-Test and Post-Test of Controlled Class Students

\begin{tabular}{|c|c|c|c|c|}
\hline No & Student's name & Pre-test & Post-test & Gained score \\
\hline 1 & A & 89 & 91 & 2 \\
\hline 2 & $\bar{B}$ & 35 & 50 & 15 \\
\hline 3 & $\mathrm{C}$ & 40 & 42 & 2 \\
\hline 4 & $\mathrm{D}$ & 31 & 34 & 3 \\
\hline 5 & $\mathrm{E}$ & 62 & 72 & 12 \\
\hline 6 & $\bar{F}$ & 48 & 39 & -9 \\
\hline 7 & $\mathrm{G}$ & 70 & 89 & 19 \\
\hline 8 & $\mathrm{H}$ & 50 & 56 & 6 \\
\hline 9 & I & 72 & 70 & -2 \\
\hline 10 & $\mathrm{~J}$ & 37 & 68 & 31 \\
\hline 11 & $\mathrm{~K}$ & 65 & 67 & 2 \\
\hline 12 & $\mathrm{~L}$ & 62 & 60 & -2 \\
\hline 13 & $\mathrm{M}$ & 60 & 76 & 16 \\
\hline 14 & $\mathrm{~N}$ & 15 & 52 & 37 \\
\hline 15 & $\mathrm{O}$ & 73 & 82 & 9 \\
\hline 16 & $\mathrm{P}$ & 65 & 70 & 5 \\
\hline 17 & $\mathrm{Q}$ & 52 & 73 & 21 \\
\hline 18 & $\mathrm{R}$ & 32 & 30 & -2 \\
\hline 19 & $\mathrm{~S}$ & 54 & 58 & 4 \\
\hline 20 & $\mathrm{~T}$ & 49 & 54 & 5 \\
\hline 21 & $\mathrm{U}$ & 15 & 65 & 50 \\
\hline 22 & $\mathrm{~V}$ & 45 & 65 & 20 \\
\hline 23 & $\mathrm{~W}$ & 79 & 60 & -19 \\
\hline 24 & $\mathrm{X}$ & 54 & 74 & 20 \\
\hline 25 & $\mathrm{Y}$ & 70 & 81 & 11 \\
\hline 26 & $\mathrm{Z}$ & 66 & 72 & 6 \\
\hline 27 & A1 & 81 & 80 & -1 \\
\hline 28 & B1 & 78 & 76 & -2 \\
\hline 29 & $\mathrm{C} 1$ & 80 & 85 & 4 \\
\hline 30 & D1 & 32 & 40 & 8 \\
\hline 31 & E1 & 49 & 45 & -4 \\
\hline
\end{tabular}




\begin{tabular}{|l|l|c|c|c|}
\hline 32 & F1 & 74 & 66 & -8 \\
\hline 33 & G1 & 38 & 55 & 17 \\
\hline & SUM & 1823 & 2097 & 276 \\
\hline & MEAN & 55.24242424 & 63.54545454 & 8.36363636 \\
\hline & MAXIMUM SCORE & 89 & 91 & \\
\hline & MINIMUM SCORE & 15 & 30 & \\
\hline
\end{tabular}

From the table 2, the highest pre-test score of controlled class students was 89 and the lowest score was 15. Meanwhile, their highest post-test score was 90, and the lowest was 30. Besides, their pre-test mean score was 55.24 and post-test mean score was 63.55. The gained mean score was 8.36. It meant that the score of controlled class students was also raised. However, it was found that the controlled class students obtained lower score than experimental class students.

\section{DISCUSSION}

According to the students, writing for English story was not easy; they needed long time to get and order ideas to write a text; they felt confused to tell the following story. Therefore, the English teachers served the students to get and expand writing skill by using technique of teaching writing recount text through rreceipts. The teacher started to explain about recount text for instance about the definition, its aim, its schematic structure, and the example of recount text through slide of power point. The teacher, then, gave some exercise such as deciding past tenses from present tense; arranging the jumbled structure of recount text.

Further, the teacher gave receipts to the students starting from the definition, the purpose, and the benefits of using receipts. The teacher gave some exercise using receipts for example making a recount text for grouping, and then each student wrote recount text using other receipts. The teacher could apply the receipt easily in the class. The students would get the ease in writing through using the receipts because in the receipts printed about the date and a description of the item the purchaser bought, business name and business number or company number the price. Therefore, teaching writing recount text using receipts is a suitable and fun way for implementing in the instructional activity.

Furthermore, after research the table 1 and table 2 proved that the experimental class students got 683 in the sum of gained score, but the controlled class students obtained it 276 . Therefore, it can be seen that the experimental class students' scores are different significantly with the controlled class students' score. The scores are different because the both classes were treated differently in teaching writing recount text; the experimental class students were given 
receipts in teaching writing recount text, but the controlled class students were not. It could be concluded that the experimental class students' writing skill was different with controlled class students after receipts served. It proved that teaching writing recount text using receipts had affected the students' writing skill. The t-test calculation showed that $\mathrm{p}<\alpha$, so HO was denied and Ha was allowed. Otherwise, if the t-test showed $\mathrm{p}>\alpha$, so HO was allowed, but Ha was denied. Therefore, the result proved that $\mathrm{p}$ was 0.049 and $\alpha$ was $0.05(\mathrm{p}<\alpha)$. It meant that there was indication Ho was denied and Ha was allowed. Further, learning writing recount text through receipts had affected positively to the writing skill of students. From the result of Cohen's calculation, the size of effect size proved 0.49 . It could be concluded that receipts had modest effect. Although the receipt does not influent powerfully to the students' writing skill of recount text, but it had effectiveness to improve writing skill of the experimental class students. It could be found through students' gained scores of the experimental class students from pre and post service. Even though not all students had not gained the score 75 as the $K K M$ (Kriteria Ketuntasan Minimal), the students' scores were raised after the treatment. Moreover, the post-test mean score of the experimental class students had proved the modest effect because gained 70.51. The mean score of the post-test is higher than the mean score of the pre-test, and it is higher than the controlled class, but it is still lower than the KKM score. So, it meant that it was found modest effect in students' writing skill of recount text through receipts.

From the research, the writer could ensure that receipts can make students' writing skill better. It can be seen from the applying of the materials in the experimental class. Students who had experienced in writing recount text using picture series, they could master English more. Further, the teacher gave receipts to the students starting from the definition, the aim, and the benefits of using receipts. The teacher gave some exercise using receipts, asked students to make recount text writing to every group, and then each student wrote recount text using receipts. The teacher applied teaching using receipt easily in the class. The students got the easy writing through using the receipts because in the receipts there are printed words of the date and description of the item purchased, business name and business number or company number, and the price. Therefore, teaching writing recount text using receipts is a suitable and fun way for implementing in the instructional activity.

\section{CONCLUSSION}

Receipt is one of meaningful printed media which can help teacher in teaching and learning process. Many advantages of using receipt can put by teacher, because they can give affect on achievement of students'learning goal. The advantages of receipt can be described as 
follow: after the students had the service by using receipt in learning writing recount text, it can be concluded that receipts had modest effect. Although the receipt does not influent powerfully to the students' writing skill of recount text, but it had effectiveness to make writing skill of the experimental class students better. It could be found through students' gained scores of the experimental class students from pre and post service. Even though not all students had not gained the score 75 as the KKM (Kriteria Ketuntasan Minimal), the students' scores were raised after the treatment. Moreover, the post-test mean score of the experimental class students had proved the modest effect because gained 70.51 . The mean score of the post-test is higher than the mean score of the pre-test, and it is higher than the controlled class, but it is still lower than the KKM score. So, it meant that it was found modest effect in students' writing skill of recount text through receipts.

The result of this study will be expected in contribution for students, teachers and further research. For the students, this study will be useful to help them to adopt creative way in learning English, especially in writing recount in order to be able to write easily and fun. For teachers, it will inform them that the receipt and gadget can be used to teach students' writing skill of recount. Teachers can also use other visual aids or media in their teaching and learning process. For researcher, this study can be one of references for further study about writing recount.

\section{REFERENCES}

Anderson, Mark. (1997). Text Type in English 2. Australia: Mackmillan.

Arikunto, Suharsimi. (2006). Metode Penelitian: Prosedur Penelitian Suatu

Pendekatan Praktik. Jakarta : Rineka Cipta.

Aqib, Zainal. (2015). Model-Model, Media, dan Strategi Pembelajaran Kontekstual (Inovatif). Bandung: Yrama Widya.

Brisk, Maria Estela. (2017). Young Bilingual Writers' Control of Grammatical Person in Different Genres. The Elementary School Journal, Vol. 112. Chichago: University of Chicago Press

Budinuryanto,j. dkk. (1997). Pengajaran Keterampilan Berbahasa. Jakarta: Depdikbud. Business. (2019). Receipts and proof of purchase. Retrieved from https://www.business.gov.au/finance/payments-and-invoicing/receipts-and-proof-ofpurchase

Djarwanto, Drs. (1994). Statistik Sosial Ekonomi. Yogyakarta: BPFE. 
Hasnida. (2015). Media Pembelajaran Kreatif. Jakarta: Luxima Metro Media.

Kementerian Pendidikan dan Kebudayaan. (2017). Model Silabus Mata Pelajaran Sekolah Menengah Pertama/Madrasah Tsanawiyah SMP/MTs).Jakarta: Kementerian Pendidikan dan Kebudayaan

Market Business News. (2020). What is a receipt? Retrieved from https://marketbusinessnews.com/financial-glossary/receipt/

Rismalarasati. (2015). Kumpulan Generic Structure Komplit 13 Jenis Teks Bahasa Inggris. Retrieved from https://rismalarasati21.blogspot.com/2015/06/kumpulan-genericstructure-komplit-13.html

Semi, M. Atar. (2007). Dasar-Dasar Keterampilan Menuls. Bandung: Angkasa.

Soeprapto, FA and Mariana Darwis. (2006). Linked to the World 3: English for senior High School, Jakarta: Yudhistira.

Sugiyono.(2010). Metode Penelitian Kuantitatif Kualitatif \& RND. Bandung: Alfabeta. 